\title{
The Nation Ex-Situ: On climate change, deterritorialized nationhood and the post-climate era
}

\author{
Maxine Burkett*
}

Abstract. It is plausible that the impacts of climate change will render certain nation-states uninhabitable before the close of the century. While this may be the fate of a small number of those nation-states most vulnerable to climate change, its implications for the evolution of statehood and international law in a "post-climate" regime is potentially seismic. I argue that to respond to the phenomenon of landless nationstates, international law could accommodate an entirely new category of international actors. I introduce the Nation Ex-Situ. Ex-situ nationhood is a status that allows for the continued existence of a sovereign state, afforded all of the rights and benefits of sovereignty amongst the family of states, in perpetuity. In practice this would require the creation of a government framework that could exercise authority over a diffuse people. I elaborate on earlier calls to use a political trusteeship system to provide the framework for an analogous structure. I seek to accomplish two quite different but intimately related tasks: first, to define and justify the recognition of deterritorialized nation-states, and, second, to explain the trusteeship arrangement that will undergird the ex-situ nation. In doing so, I introduce the notion of a post-climate era, in which the very structure of human systems - be they legal, economic, or socio-political-are irrevocably changed and ever-changing.

\section{INTRODUCTION}

It is plausible that by the close of this century the impacts of climate change will render certain states in the Pacific and Indian Oceans uninhabitable. The geo-political consequences-not to mention the devastation to the nations and peoples at issue-will be great and unprecedented. This is significant despite the relatively small number of individuals affected. In short, this loss of land

* Associate Professor of Law, University of Hawai'i, William S. Richardson School of Law; JD University of California Berkeley (Berkeley Law); BA Williams College. <burkettm@hawaii.edu> I thank Michael Gerrard, Robert Perkinson, Joshua Stanbro, Gregory Wannier, the participants of the Center for Climate Change Law's Spring 2011 conference, Threatened Island Nations: Legal Implications of Rising Seas and a Changing Climate, and the Climate Law editor and referees, for their invaluable feedback. For research assistance, I thank Amy Brinker, Trevor Tamashiro, and Kylie Wager. 
may create a conundrum for international law, which is equipped to deal with relatively neater circumstances of stateless individuals or expiring states. Optimally, there would be sufficient political will and commitment at the international level to reduce emissions aggressively and ensure the continued habitability of all states. Absent any indication of such swift action, however, international law should now find a suitable resolution for the nation-states that will lack a territory. In response to this phenomenon, I argue that international law can accommodate a new category of international actors: the Nations Ex-Situ. ${ }^{1}$

Ex-situ nationhood would be a status that allows for the continued existence of a sovereign state, afforded all the rights and benefits of sovereignty amongst the family of nation-states, in perpetuity. It would protect the peoples forced from their original place of being by serving as a political entity that remains constant even as its citizens establish residence in other states. It is a means of conserving the existing state and holding the resources and well-being of its citizens-in new and disparate locations-in the care of an entity acting in the best interest of its people. ${ }^{2}$

In practice, this would require the creation of a government framework that could exercise authority over a diffuse people. Other scholars have suggested a resurrection of the political trusteeship system as a means for administering the duties of a deterritorialized government. Here, I elaborate on those proposals and recommend a hybrid structure that provides a permanent space for long-distance, and perhaps collaborative, governance of Nations Ex-Situ.

In this article, therefore, I seek to complete two quite different but intimately related tasks. First, I will demonstrate that the recognition of a Nation Ex-Situ is a novel but justified interpretation of the state, one that international law could tolerate and incorporate into its existing definitions. To the extent that critics deem this an impossible departure from existing norms, I argue that the exigencies of the soon-to-be-landless favour new and creative ways for states to exist in the international community. Second, I demonstrate that a modified political trusteeship system is a viable model for effective participation in the international community, given the scenarios presented by those displaced by climate change. A key element of this arrangement would be the continued self-governance of those nations by trustees who are elected by their peers and who act for the benefit of the ex-situ nation. (This would not be a reprise of their-in some cases - prior trustee relationships.) I then detail integral elements of this arrangement as applied to the peculiar circumstances of endangered states.

The article proceeds as follows. Part II provides a background on climate-induced migration and explores the unique and urgent plight of small-islanders and threatened nation-states. To be clear,

\footnotetext{
${ }^{1}$ In this article, I use "nation" or "nationhood" to describe the unified peoples described above. I use "state" or "statehood" to describe the entity that is the constitutive element of the international community. The nation-state describes the sovereign state comprised of, or inhabited by, a unified people.

${ }^{2}$ Here, I borrow conceptually from the practice of $e x$-situ conservation, which literally means "off-site conservation", and describes the practice of protecting an endangered population outside of its natural habitat. The analogy is not drawn between species and peoples but between species and this creature of international law-the nation-state, which is an elemental organism of the international law taxonomy.
} 
while I provide a discussion of climate migration generally, this article addresses the specific plight of states whose territories are rendered uninhabitable due to total submersion or chronic processes that so thoroughly compromise their land that there is no longer a viable source of food, water, or other necessities needed to sustain human communities. Part III argues for a re-envisioning of the state, in which a deterritorialized state, or Nation Ex-Situ, is an alternative form of statehood recognized as consistent with, or a natural extension of, existing international law norms. In supporting this assertion, I do three things: I demonstrate that alternative forms of the state are not novel, and briefly point to examples of entities that provide a precedent. I then identify elements of cosmopolitan theory, as well as the evolving conditions of various diasporas, that show that a landless - or "virtual"-state is appropriate here, and is, at the same time, an inevitable evolution of contemporary citizenship and statehood. Finally, I argue that if none of these arguments avails, the extraordinary circumstances of threatened states alone could justify the proposed unique departures from the norm.

Part IV provides a framework for how the Nation Ex-Situ might operate. I first describe what a trusteeship arrangement would look like for deterritorialized states in transition and the establishment of permanent ex-situ status. I then identify the advantages that would inure to both the new state, as a political entity, and to its diasporic citizens. I also briefly discuss how this kind of arrangement may impact the states that host the deterritorialized citizens of the Nation Ex-Situ. I conclude with a brief experiment in which I apply the new arrangement to a supposed scenario for the Republic of the Marshall Islands - one of the atoll nation-states that may be landless before the close of the century. By playing out the implications of "The Republic of the Marshall Islands $E S ",{ }^{3}$ thorny issues of history and sovereignty become clearer.

Finally, in Part V, I consider how endangered states are a quintessential example of the fundamental shifts that may continue to confront the law because of climate change. The legal questions raised regarding the meaning of the "state", as defined by international law, present novel and complex challenges to contemporary jurisprudence. International law operates within the narrow band of principles for statehood and sovereign relationships that marks the contemporary Westphalian organization of the global community. While there is room for elements of creativity and novel interpretation, there is an expectation of consistency and coherence that climate change fundamentally calls into question. This is true for the entire discipline of law, which, I contend, may require a re-envisioning of itself to accommodate the unique circumstances of climate-induced human migration in the twenty-first century. In sum, if today the "law" strives for consistency, universality, and predictability, then the challenges of addressing climate change - in the broadest sense, beyond issues of migration and loss of territory - may instead require flexibility, individual application, and responsiveness.

To give theoretical structure and integrity to this fundamental shift in understanding that the law might undergo, I argue that we are embarking on a new legal and political epoch. It is

\footnotetext{
${ }^{3}$ The Republic of the Marshall Islands ES would be the short form used for the ex-situ nation, in which "ES" stands for $e x$-situ.
} 
the post-climate era. ${ }^{4}$ To be clear, "post-climate" describes a theory that is relevant today, as the impacts of climate change grow increasingly palpable, and physical phenomena occur that might not have occurred in the absence of human-induced changes to the climate system. ${ }^{5}$ This shift is not unique to international law. International law is simply among the legal fields first in the queue for analysis, deconstruction, and evolution.

\section{Climate-Induced Migration And Loss Of Habitable Territory Explained}

Migration-the process of population movement either across an international border or within a state-is the expected result of loss of habitable land. Recent data showing an increase in extreme weather events, from droughts to cyclones, may portend more tenuous circumstances for millions. For example, the number of recorded annual natural disasters has doubled from approximately 200 to 400 per year over the past twenty years. Nine out of ten of these can be considered climate-related. ${ }^{6}$ This situation of more frequent and severe disasters may be the "new normal." Sea-level rise, of particular concern to coastal communities and small island states, may result in the loss of habitable territory and the displacement of ten per cent of the world's population. ${ }^{8}$ These climate-related impacts foretell significant human impacts, even if researchers cannot state precisely the exact nature, timing, and magnitude of the impacts. For this reason, certain regions will need to exercise marked vigilance to prepare for potentially large-scale migration.

Large-scale migration of peoples and communities due to climate change may have a dramatic effect on the globe in the next half-century. It is estimated that some two hundred million people worldwide may presently be on the move because of increased storms, flooding, sea-level rise, and desertification. ${ }^{9}$ From Bangladesh to Papua New Guinea, loss of homeland is already occurring and may accelerate as slow-onset and sudden disasters due to climate change compromise human habitats. For small-islanders, in particular, the perils of migration-including loss of livelihood

\footnotetext{
${ }^{4}$ Parallel to, perhaps, the Anthropocene. Humanity's impact on the Earth's climate and ecosystems has inspired some to suggest that the most recent geological epoch, the Holocene, was abruptly ended by the launch of the Anthropocene during the industrial revolution. See, e.g., Elizabeth Kolbert, Enter the Anthropocene-Age of Man, National Geographic, March 2011, <http://ngm.nationalgeographic.com/2011/03/age-of-man/kolbert-text>. This shift in nomenclature suggests, then, that humans have had an impact on the global environment comparable to a new ice age.

5 "Post-climate" does not describe a theory useful once climate change impacts have ceased. Indeed, for all intents and purpose on timescales relevant to human beings, climate change is irreversible. See Susan Solomon et al., Irreversible Climate Change due to Carbon Dioxide Emissions, 106 Proceedings of the National Academy of Sciences 1704 (2009).

${ }^{6}$ Vikram Kolmannskog, Legal Coordinator, Norwegian Refugee Council, DIIS Brief: Climate of Displacement, Climate for Protection? (10 December 2008).

${ }^{7}$ Vikram Kolmannskog, Norwegian Refugee Council, Climate Changed: People Displaced (Richard Skretteberg, ed., 2009).

${ }^{8}$ Hannah Devlin, Nations will vanish and millions lose their homes to rising seas, The Times, 1 December 2009, www.timesonline.co.uk/tol/news/environment/article6938378.ece.

${ }^{9}$ Nicholas Stern, The Economics of Climate Change: The Stern Review 56 (2006); see also International Organization for Migration [IOM], Compendium of IOM's Activities in Migration, Climate Change and the Environment, at $16(2009)$.
} 
and culture, and integration in a host country or community - is made worse by the loss of their state. In other words, while displacement within and across borders may be a compulsory journey for many "climate migrants", small-islanders will be on the move absent a country - with all of its attendant legal, economic, and cultural markers-to which to return.

While the absolute number of small-islanders who may need to move is likely quite small, the consequences of sea-level rise to their communities are significant, making their plight worthy of focus. Impacts of climate change may exacerbate pre-existing vulnerabilities typical of nationstates of similar size and stage of development. For certain states, however, climate change and associated sea-level rise threaten the very survival of their entire territory. This consequence, particularly when juxtaposed with their meager contribution to global warming, is also compelling when viewed through an ethical, legal, or geopolitical lens. It becomes particularly consequential as it promises to significantly challenge the law and policy underpinnings of the modern Westphalian order.

It has been twenty years since the Intergovernmental Panel on Climate Change first stated that the "gravest effects of climate change may be those on human migration". ${ }^{10}$ The IPCC again addressed the issue in its Fourth Assessment Report. There it suggested caution in linking and predicting the degree to which climate change impacts will influence migration. ${ }^{11}$ Indeed, the emerging crisis of climate-induced migration has not been given the attention at the geopolitical scale that is commensurate with the potential scope of the problem. A number of challenges inherent to the migration discourse aid this political lethargy. A persistent lack of information undermines the conversation in three main respects: (i) estimating the number of people that will need to move in the next two generations; ${ }^{12}$ (ii) identifying the type of migration that an arbiter could causally attribute to climate change, as distinct from the normally multi-causal influences on migration; ${ }^{13}$ and, (iii) affixing the appropriate term on those who will move. ${ }^{14}$

\footnotetext{
${ }^{10}$ First Assessment Report, Policy Maker Summary of Working Group II: Potential Impacts of Climate Change, Intergovernmental Panel on Climate Change [IPCC], para. 5.0.10, at 103 (1990). This statement was substantiated by the IPCC's Fourth Assessment Report. Contribution of Working Group II to the Fourth Assessment Report of the Intergovernmental Panel on Climate Change, Climate Change 2007: Impacts, Adaptation and Vulnerability, IPCC (M.L. Parry et al. eds., 2007) [hereinafter IPCC, Working Group II (2007)].

${ }^{11}$ IPCC, Working Group II (2007), at 365.

${ }^{12}$ IOM, Compendium, supra note 9.

13 Though the actual causes of migration are manifold, there are a few pertaining to climate change that remain relevant. Individuals and communities will be on the move due to real or perceived increases in environmental hazards, and their attendant alteration of resource conditions. Adaptation policy and practice will also govern the movement of peoples. For example, in the People's Republic of China, environmental migration is a component of stated policy currently limited to the impoverished who must leave predominantly rural, ecologically fragile areas to resettle. Asian Development Bank, "Climate Change and Migration in Asia and the Pacific", Draft Executive Summary (2009) (on file with author). Risk perception also serves as a good indicator of migration due to climate change. Ibid. See also Melissa L. Finucane, Why Science Alone Won't Solve the Climate Crisis: Managing Climate Risks in the Pacific, 89 AsiaPacific Issues 1, at 1-8 (2009).

${ }^{14}$ To the extent that one can directly link a given climate-related storm, for example, and the displacement of peoples in its path, there is no agreed upon definition for those dislocated. "Climate refugees" has been the mostly widely used term in popular discourse, which certain scholars vigorously defend. From a law and policy standpoint, however, the term "refugee" is not an accurate reflection of the legal status of these migrants. In fact,those
} 
This lack of clarity goes together with an absence of legal protection. These individuals and communities exist in a veritable legal no-man's land. Many international instruments, norms, conventions, and covenants govern forced displacement due to persecution, conflict, and disasters. ${ }^{15}$ The most relevant to the subject matter are the 1951 Geneva Convention Relating to the Status of Refugees- the key legal document in defining who is a refugee, their rights, and the legal obligations of states - and the United Nations Framework Convention on Climate Change, a treaty addressing the manner in which states mitigate and adapt to the effects of climate change. Neither document has embraced climate-induced migration. The Refugee Convention does not cover such migrants, and there is no consensus to amend the treaty to provide for them. ${ }^{16}$ The UNFCCC and the Kyoto Protocol do not acknowledge the great policy needs raised by climateinduced migration beyond cursory references to the threats to habitability and sovereignty that small island developing states face. ${ }^{17}$ In fact, because the international legal regime has resisted the cross-cutting impacts of climate on migration, and because there are many other areas of the law that climate migration implicates-including development, national security, and human, indigenous, and cultural rights - this issue may continue to fall through the cracks. No one area of the law owns climate migration. ${ }^{18}$

With these challenges and the absence of adequate empirical information, the plight of climate migrants is easily sidestepped. This might continue to occur in the larger context of global migration. For small island states, however, there are compelling reasons to act in the near term. In particular, for small-islanders, the assumption that climate change might lead in a linear way to

dislocated due to impacts reasonably related to climate change have no legal status at all. As a result, scholars, researchers, and some political voices employ proxy terms such as "climate migrants" or "the climate displaced" in order to avoid thorny terminology. Finding an appropriate term is vital, as clearly defined and articulated legal categories delimit the rights of individuals and the concomitant obligations that bind relevant states and the international community. See, e.g., Frank Biermann and Ingrid Boas, Preparing for a Warmer World: Towards a Global Governance System to Protect Climate Refugees, at 8 (Global Governance Project, Working Paper No. 33, Nov. 2007). Biermann and Boas argue: "Why should inhabitants of some atolls in the Maldives who require resettlement for reasons of a well-founded fear of being inundated by 2050 receive less protection than others for fear political persecution?" Ibid. In some cases, the refugee label is not preferred due to the very implication of passivity and victimization the term connotes. See Jane McAdam, Environmental Migration Governance, in University of New South Wales Faculty of Law Research Series, at 7 (Univ. of New South Wales, Paper No. 1, 2009) [herein after Environmental Migration].

${ }^{15}$ Roger Zetter, IOM, The Role of Legal and Normative Frameworks for the Protection of Environmentally Displaced People, in Migration, Environment and Climate Change: Assessing the Evidence, at 391 (Frank Laczko and Christine Aghazam, eds., 2009).

${ }^{16}$ See, e.g., Biermann and Boas, supra note 14, at 19; Forced Displacement in the Context of Climate Change: Challenges for States Under International Law, UN High Commissioner for Refugees [UNHCR], at 10 (19 May 2009), available at $<\mathrm{http} / /$ www.unhcr.org/refworld/docid/4a2d189ed.html $>$ (arguing that any initiative to modify the refugee definition would risk a renegotiation of the Convention, which, in the current political environment, might undermine the international refugee protection regime altogether).

${ }^{17}$ UNFCCC (2007: 25) and UNFCCC (2007 : 42) cited in Philippe Boncour and Bruce Burson, Climate Change and Migration in the South Pacific Region: Policy Perspectives, at 7 (2009).

18 The numerous cross-cutting and intersecting issues raised by climate-induced migration may result in the issue being dealt with in an ad hoc and fragmented manner. McAdam, Environmental Migration, supra note 14 , at 23. 
migration is not so controversial. Indeed, recent climate science suggests that, for the Pacific atoll states, inundation is a distinct possibility, as IPCC estimates of sea-level rise increasingly appear overly conservative. ${ }^{19}$ Sea-level rise and other related climate impacts might render certain state territories uninhabitable, perhaps as early as 2050 .

\section{The Unique Case of Small Island States Requires Immediate and Particularized Attention}

The circumstances of climate migrants from small island states in the Pacific and Indian Oceans ${ }^{20}$ will differ in several respects from dislocations that the global community has previously witnessed. ${ }^{21}$ Unlike their contemporary counterparts, these climate migrants are marked by several factors: an inability to return to their homes, collective migration, a predictable need for migration, and a unique and compelling moral element to their situation. ${ }^{22}$

Small island states rely heavily on coastal resources for subsistence. ${ }^{23}$ Sea-level rise, coastal inundation, seawater intrusion into freshwater sources, and soil salinization compromise freshwater availability and adversely affect coastal agriculture. ${ }^{24}$ Indeed, this is already occurring in some Pacific island communities. In the Federated States of Micronesia, food and water insecurity due to sea-level rise is already among the nation's top problems. ${ }^{25}$ More frequent extreme spring tides, known as "king tides", have damaged coastal infrastructure and staple foods such as taro, as well as soil and agro-forestry resources in coastal settings, particularly in the low-lying atoll islets of Micronesia. The attendant impacts on various sectors of the economy, including tourism for some island states, is also largely negative. ${ }^{26}$ Further, negative impacts on traditional knowledge and cultural sites are already occurring and may accelerate. $^{27}$

\footnotetext{
${ }^{19}$ See, e.g. Martin Vermeer and Stefan Rahmstorf, Global Sea Level Linked to Global Temperature, 106 Proceedings of the National Academy of Sciences 21, 527-532 (2009) (concluding that if their method presents "a reasonable approximation of the future sea-level response to global warming, then for a given emission scenario sea level will rise approximately three times as much by 2100 as the projections (excluding rapid ice flow dynamics) of the IPCC AR4 (2) have suggested"); E. Rignot et al., Acceleration of the contribution of the Greenland and Antarctic ice sheets to sea level rise, 38 Geophysical Research Papers 5 (2011) (discussing the impacts of glacial ice sheet loss on global sea-level rise and concluding that the "magnitude of the acceleration suggests that ice sheets will be the dominant contributors to sea level rise in forthcoming decades, and will likely exceed IPCC projections for the contribution of ice sheets to sea level rise in the 21 st century").

${ }^{20}$ While this article is relevant to all endangered states, I focus moreseo on a broad Pacific island experience.

${ }^{21}$ Biermann and Boas, supra note 14 , at 15 .

${ }^{22}$ Ibid., at $15-16$.

${ }^{23}$ Nobuo Mimura et al., Small Islands, in IPCC, Working Group II (2007), supra note 10, at 693.

${ }^{24}$ Ibid.

${ }^{25}$ Charles H. Fletcher and Bruce M. Richmond, Climate Change in the Federated States of Micronesia: Food and Water Security, Climate Risk Management, and Adaptive Strategies, at 9 (2010)<http://icap.seagrant. soest.hawaii.edu/climate-change-federated-states-of_micronesia>. According to NASA Satellite maps, Micronesia's inhabits the spot where sea level is rising most rapidly. Rachel Morris, "What Happens When Your Country Drowns?" Mother Jones, Nov/Dec 2009.

${ }^{26}$ Mimura, supra note 23, at 689 .

${ }^{27}$ Ibid., at 690. See also Boncour and Burson, supra note 17, at 11 (describing the impacts on winds and crop planting in the Solomon Islands).
} 
Migration due to rising seas is a squarely climate-change-linked phenomenon, for which past migration experience provides little guidance and international law provides no relief. This is true despite that fact that the "potential abandonment of sovereign atoll countries can be used as a benchmark of the 'dangerous' change that the UNFCCC seeks to avoid". ${ }^{28}$ Further, it is important to note explicitly that long before the ocean submerges them, other dynamics of climate change are very likely to render low-lying island states uninhabitable. ${ }^{29}$ The loss of fresh water sources and arable land, damage to their near-shore marine environment, and the attendant destruction of their economic base may force external displacement of entire populations and their governments. ${ }^{30}$

To date, emigration from uninhabitable regions and resettlement has occurred in pockets of the Pacific. The ongoing internal migration in Papua New Guinea of 2,600 islanders from the lowlying Carteret Islands to Bougainville is considered the first in which an island community has undergone a coordinated relocation due to encroaching seas. ${ }^{31}$ This kind of internal migration is a relative luxury, as a number of atoll states lack internal refuge due to the lack of higher ground. ${ }^{32}$

Countries like the Maldives, Tuvalu, and Kiribati have challenged the nature and content of the international climate change discourse by highlighting the inevitable loss of their entire homeland, and its attendant legal and cultural value. The Maldives, an archipelago of 1,190 islands in the Indian Ocean with an average elevation of four feet, could see portions of its capital flooded by $2025 .{ }^{33}$ Its president, Mohamed Nasheed, has been quite public in his desire to acquire land outside of traditional borders and move all 300,000 Maldivians to safer territory. While Tuvalu

\footnotetext{
${ }^{28}$ Mimura, supra note 23, at 707 (quoting Jon Barnett and W. Neil. Adger, Climate Dangers and Atoll Countries 321-37 (2003)).

${ }^{29}$ See Fletcher and Richmond, supra note 25, at 16 (explaining that before the fate of the island land mass is determined by overwash, it will have become uninhabitable due to salt water intrusion into aquifers, wetlands, and soils that will contaminate food and water resources). The authors go on to explain: "The debate among geologists regarding the fate of atoll islets neglects one point that is important to clarify for the media who tell the FSM story. Marine inundation, the same process that carries sediment to the island interior, is extremely damaging to atoll fresh water supplies, the soil, the forests that supply food and the wetlands in which island residents grow taro as a consumable staple. Long before the question of atoll landforms surviving sea-level rise is settled, human communities will have been forced to abandon these environments unless a climate adaptation strategy is developed that provides them with potable water and sufficient food. Ideally, adaptation steps can be implemented to secure the tenure of additional generations of families before, and if, abandonment becomes necessary". Ibid., at 22.

${ }^{30}$ See ibid.; Climate Change and Statelessness: An Overview, UNHCR (15 May 2009), available at <http://www.unhcr.org/refworld/docid/4a2d189d3.html> [hereinafter UNHCR, Climate Change].

31 A small community living in Vanuatu may also hold this dubious distinction. Charles Di Leva and Sachiko Morita, Maritime Rights of Coastal States and Climate Change: Should States Adapt to Submerged Boundaries? (World Bank, Law and Development Working Paper Series No. 5, April 2008).

${ }^{32}$ Indeed, this is a relative luxury for small island nations, generally. See Dominic Kniveton et al., Challenges and Approaches to Measuring the Migration-Environment Nexus, in Migration, Environment and Climate Change: Assessing the Evidence, IOM, at 74 (2009) (describing the 1995 evacuation of Martinique due to an imminent volcanic eruption).

33 United Nations Development Programme, Developing a Disaster Risk Profile for Maldives, Vol. 1 and 2 (May 2006), available at <www.mv.undp.org/v2/publication_files/4b35f384ace8d.pdf>.
} 
is similarly vulnerable, it, like some other small island states, has not wanted relocation to figure prominently in international agreements, lest industrialized countries deem relocation a quicker, easier fix than emissions reductions. ${ }^{34}$ Nevertheless, countries like Tuvalu and Kiribati have had to contemplate the loss of their country and have begun early discussions with larger, industrialized countries, like Australia and New Zealand. Though the type of migration explored has largely focused on enhanced labor migration, deeper investigation into migration and resettlement alternatives with these countries appears likely.

\section{The Challenges of Sovereignty and Statelessness}

As evidenced above, climate change for small island states may yield environmental change so "dramatic and all-encompassing of livelihoods that... most or all inhabitants will be forced to migrate". ${ }^{35}$ This will not occur instantaneously, but over time. Ambassador Ronald Jumeau, the Seychelles' Ambassador to the United Nations and the United States, has expressed concerns about climate change rendering his state a failed one. ${ }^{36}$ Vital questions arise, as a result: "When you relocate and you lose your country, what happens? What's your status in the country you relocate to? Who are you? Do you have a government there? Government of what?"37 It is quite plausible that these questions will arise before the entire population moves, as certain indicia of statehood-such as a permanent population and a functioning government-are compromised in advance of mass migration or total resettlement. ${ }^{38}$ Further, when island states are no longer inhabited and the population is permanently displaced to other countries, it is unclear whether those citizens will become stateless persons under international law or landless citizens of a state that no longer exists. ${ }^{39}$

\footnotetext{
${ }^{34}$ Kolmannskog, supra note 7 , at 15 .

${ }^{35}$ Zetter, supra note 15 , at 396 . Four completely atoll nations in the Pacific are particularly vulnerable. They are Kiribati, Tokelau, Tuvalu, and the Republic of the Marshall Islands.

${ }^{36}$ Seychelles Sink As Climate Change Advances (National Public Radio broadcast 22 September 2010). Although there are hills, eighty percent of the Seychelles population live on the coasts and their airport is built on land reclaimed from the ocean.

37 Ibid.

${ }^{38}$ As enumerated in the Restatement (Third) of Foreign Relations and the Montevideo Convention, international law generally regards a "state" to have four key elements. Criteria for statehood include (i) a permanent population; (ii) a defined territory; (iii) a functioning government; and, (iv) the capacity to enter into relations with other states. Restatement (Third) of Foreign Relations 201 ("Under international law, a state is an entity that has a defined territory and a permanent population, under the control of its own government, and that engages in, or has the capacity to engage in, formal relations with other such entities".); Montevideo Convention on the Rights and Duties of States art. 1, 26 December 1933, 49 Stat. 3097, 3 Bevans 145. See generally James Crawford, The Creation of States in International Law (2 $2^{\text {nd }}$ ed., 2006); Jane McAdam, 'Disappearing States', Statelessness and the Boundaries of International Law, in Climate Change and Displacement: Multidisciplinary Perspectives (Jane McAdam, ed., 2010) [hereinafter 'Disappearing States']. A nomadic or unorganized way of life might undermine claims to sovereignty. See Martti Koskenniemi, The Gentle Civilizer of Nations 140 (2002). The ex-situ nation might actually aid in maintaining organization for a dispersed community.

${ }^{39}$ See Zetter, supra note 15, at 428 (explaining that such people will still have a nationality, despite being landless and stateless, but conditions of statelessness are different from those normally covered by stateless conventions); see also McAdam, Environmental Migration, supra note 14, at 17; McAdam, 'Disappearing States', supra note 38. The full implications for resettlement are beyond the scope of this paper. Though the details of this arrangement is what would be mediated by the interim body for the Nation Ex-Situ. See discussion infra Part IV.
} 
The relative near-term dissolution of a country's habitable territory due to climate change, the phenomenon I refer to as endangered states, ${ }^{40}$ raises novel questions that may challenge the very foundation of Westphalian, or nation-state, sovereignty. ${ }^{41}$ The international personality of states, particularly their creation and disappearance, is admittedly one of the most complex areas of law. There are international law regimes that govern issues of deprivation of nationality following the succession of a state, for example. There are none, however, that govern circumstances in which no successor state exists and the predecessor state has been rendered uninhabitable or has physically disappeared. ${ }^{42}$

There is evidence, however, that while statehood is a legal concept with a determinate content, it is flexible. ${ }^{43}$ Notably, substantial changes in territory, population, or government, or even a combination of all three, do not necessarily extinguish a state. ${ }^{44}$ In fact, in the period since the signing of the UN Charter, there have been very few cases of state extinction and almost no cases of involuntary extinction. ${ }^{45}$ Further, each of the elements that are central to the concept of a state "may present significant problems in unusual situations", ${ }^{46}$ suggesting that statehood as a flexible legal concept is appropriate. That possibility for flexibility coupled with the strong presumption that favours the continuity and disfavours the extinction of an established state ${ }^{47}$

\footnotetext{
${ }^{40}$ Endangered states include those identified as "sinking island states" by the United Nations High Commissioner for Refugees. UNHCR, Climate Change, supra note 30. They are the Maldives, Tuvalu, Kiribati and the Republic of the Marshall Islands.

${ }^{41}$ Less dramatically, though significant, with sea-level rise, coastlines may shift or submerge with potential implications for the rights of coastal states over their maritime zones. See Di Leva and Morita, supra note 31. Crucial questions raised as a result will be whether maritime boundaries can shift and whether a country's right to explore offshore resources will be affected, among others. Ibid.

${ }^{42}$ See UNHCR, Climate Change, supra note 30 (explaining that there is no precedent for the loss of an entire territory or the exile of an entire population); McAdam, Environmental Migration, supra note 12 (explaining that it is unprecedented for a state to disappear altogether, as opposed to being reconstituted as another through extinction or merger, for which laws of State succession apply).

${ }^{43}$ Crawford, supra note 38, at 718. For a strong critique of the current understanding of the "state", see Guido Acquaviva, Subjects of International Law: A Power-Based Analysis, 38 Vand. J. Transnat'1 L. 345 (2005) (challenging the definition of the term "state" that is commonly accepted in legal scholarship as the basis for assessing whether an entity is a subject of international law and concluding that the only essential element of a subject of international law is its sovereignty).

${ }^{44}$ Crawford, supra note 38, at 700. See also McAdam, 'Disappearing States', supra note 38. McAdam explores the creation of states in the climate change context to determine at what point the absence of certain criteria of statehood might lead other states to deny a state's continued existence. Ibid., at 110 . Indeed, an effective government may be the most important criterion for statehood, since all others depend on it. Ibid., at 113.

${ }^{45}$ Crawford, supra note 38, at 715. Relevant to this article, Crawford notes: "It is significant that almost all the cases of extinction listed above involved either entities that were ephemeral or whose independence was not clearly established or were instances of voluntary extinction, when a people. . or their representatives... decided to put an end to their State and to opt for a different future". Ibid.

${ }^{46}$ Restatement (Third) of Foreign Relations 201 (1987); see also Acquaviva, supra note 43, at 349 ("Uncommon situations test the veracity and reliability of the definition itself, at least if the definition is to serve any practical purpose".).

${ }^{47}$ UNHCR, Climate Change, supra note 30 (stating that to the extent that statelessness is foreseeable, efforts should focus on preventing it from arising, consistent with the principle of prevention of statelessness recognized in international law as a corollary to right to a nationality); McAdam, 'Disappearing States', supra note 38. McAdam argues that the lack of all four indicia of statehood (i.e., a defined territory, a permanent population,
} 
suggests that acceptance of creative interpretations of law to recognize the continued existence of a state-particularly in this "unusual situation" - is plausible. ${ }^{48}$

\section{Re-envisioning the State}

"But the substrate of the State is not property, it is the people of the State seen as a collective". ${ }^{49}$

Climate change will require meaningful interpretations of the law and may sometimes justify significant departures from precedent or the legal status quo. Accordingly, new positive rules that recognize a novel category of "state" as a consequence of the changing landscape may be essential. ${ }^{50}$ As a practical matter, resolving existing maritime entitlements, for example, could be made easier for endangered states if the international community recognizes a new kind of state. ${ }^{51}$ For these key administrative and economic concerns, as well as to confront the deeper dilemma of threats to sovereignty and culture, the international community could agree that affected states will continue to exist. ${ }^{52} \mathrm{I}$ argue that a deterritorialized statehood is an appropriate means for continued existence. ${ }^{53}$

an effective government, and the capacity to enter into relations with other states) may not mean the end of a state.

${ }^{48}$ Crawford, supra note 38 , at 701. But see UNHCR, Climate Change, supra note 30 (stating that although there is no internationally agreed definition of what constitutes a state, there is agreement in the existing doctrine that there must be territory inhabited by a permanent population under control of an effective government). For further discussion of the propriety of deterritorialized statehood, see discussion infra Part III.3.

${ }^{49}$ Ibid., at 717. "In a true union, according to Grotius, nothing is lost, not even personality". Ibid. (citing Grotius, De Jure Belli ac Pacis, Bk II, ch IX: "Whenever two peoples are united, their rights will not be lost but will be shared in common). Of course the substrate of the Pacifica Islands people is, in many cases, their land. That poses a fundamental issue regarding the slow and inadequate pace of climate change mitigation through emissions reduction - an important consideration that is beyond the scope of this paper.

${ }^{50}$ Although the 'what' and 'how' remain unresolved, it is agreed that new rules of international law will be necessary to provide "stability, certainty, and a future" to endangered nation-states. Rosemary Rayfuse, International Law and Disappearing States: Utilising Maritime Entitlements to Overcome the Statehood Dilemma, in University of New South Wales Faculty of Law Research Series, at 1 (Univ. of New South Wales, Paper No. 52, 2010) [hereinafter International Law].

${ }^{51}$ Several scholars have written on the possible impacts to existing maritime entitlements. See, e.g., Rayfuse, International Law, supra note 44; Di Leva and Morita, supra note 31. Recognition of states "is the act through which a subject of international law indicates its willingness to enter into inter-state relations with another subject of international law and thus is evidence-but not proof - that the latter has acquired international personality". Acquaviva, supra note 43, at 350. Consistent with his overall critique, Acquaviva goes on to explain why recognition may not logically establish the international personality of states; and is, in fact, "merely a political choice, with no effective bearing on the qualification of an entity as a subject of international law". Ibid., at 364. The key, again, is sovereignty.

52 UNHCR, Climate Change, supra note 30, at 2; McAdam, 'Disappearing States', supra note 38, at 113.

53 There are, of course, other possibilities, including acquiring new territory from a distant state by treaty of cession. See UNHCR, Climate Change, supra note 30, at 2; Rayfuse, International Law, supra note 50, at 7. Though, Rayfuse rightly points out the practical impediments to such a solution - namely that it is difficult to imagine any state agreeing to cede any portion of its land. "The political, social and economic ramifications of ceding valued and/or inhabited territory may simply exceed the capacities - and courage - of existing governments". Rayfuse, International Law, supra note 50 , at 8 . 
Deterritorialized statehood as an alternative future for endangered states is not a new concept. Others have contemplated such a successor entity. ${ }^{54}$ In particular, Rosemary Rayfuse has briefly introduced the possibility, arguing: "Ultimately, a more equitable solution may lie in recognition of a new category of deterritorialised state" ${ }^{55}$ No-one, however, has elaborated on how to further define and justify this kind of statehood, or a "new category of international personality... in the context of existing states". 56

In this section I identify alternative forms of the state and entities that are tantamount to state actors. I then identify elements of cosmopolitan theory, as well as the evolving conditions of various diasporas, that show that a landless state is appropriate here, and is, at the same time, an inevitable evolution of contemporary citizenship and statehood under the circumstances. Finally, I argue that if none of these is persuasive, the extraordinary circumstances of threatened nation-states alone can justify such unique departures from the norm.

\section{Alternative Forms of the State as Precedent}

Noteworthy historical instances of deterritorialized governance demonstrate that the deterritorialized state is neither new nor inconceivable under current international law. Three existing categories of international actors provide clear precedent for the deterritorialized states proposed. They are (i) countries that have governed without a territory; (ii) "failed states" 57 and governments in exile; and (iii) economic entities that serve quasi-governmental roles. Other scholars have elaborated on their relevance to the phenomenon of endangered states. ${ }^{58}$ I briefly summarize each here.

Rayfuse identifies and elaborates on the Sovereign Military Order of Malta and the Holy See as governance entities without a territory that participate in international relations on a par

\footnotetext{
${ }^{54}$ Rayfuse, International Law, supra note 50 (introducing the concept of "deterritorialised state" and argues for its application as basis for continuing recognition of sovereignty of disappeared states over their pre-existing maritime zones and resources therein).

${ }^{55}$ Rayfuse, International Law, supra note 50. Rayfuse acknowledges that a full analysis of the issue is beyond the scope of the paper. Ibid., at 9.

${ }^{56}$ Rayfuse explicitly states that nothing proposed in her article is "intended to suggest a new category of international personality available to peoples, however defined, raising current or future self-determination claims in context of existing states". Ibid., at 10.

${ }^{57}$ But see Crawford, supra note 38, at 721 (discussing the thorny issues surrounding the term 'failed State', its differing perception among developed and developing states, and the ways in which the designation has been used to justify "questionable exercises in international intervention"). Crawford clarifies the conceptual confusion behind the use of "failed States", explaining that the situations described "are, evidently, crises of government... or governance". Ibid., at 721-22.

${ }^{58}$ See, e.g., Rayfuse, International Law, supra note 50; Rosemary Rayfuse, (W)hither Tuvalu? International Law and Disappearing States, in University of New South Wales Faculty of Law Research Series (Univ. of New South Wales, Paper No. 9, 2009) (on file with the author) [hereinafter (W)hither Tuvalu?]; McAdam, 'Disappearing States', supra note 38.
} 
with landholding states. ${ }^{59}$ International law recognizes the former as a sovereign subject, though it is headquartered in Rome and lacks traditional markers of statehood-namely, a permanent population and territory. ${ }^{60}$ The Papal See is similar. ${ }^{61}$ It has consistently enjoyed full legal personality under international law, maintains diplomatic relations with most states, and participates in intergovernmental and international agreements. ${ }^{62}$ Importantly, the historical changes in territorial control, as well as population, have not affected the international personality of the Holy See. ${ }^{63}$

Governments in exile are examples of functional, yet non-territorial, sovereignty that international law also recognizes. Palestinians and indigenous nations, such as the Maori or Tibetans, are examples of these communities that the processes of invasion or colonization have internally dislocated or formally deterritorialized. ${ }^{64}$ Indeed, history is "replete with examples" of governments operating in the territory of other states. ${ }^{65}$ Assuming no interference in the exiled government's functions, its independence is preserved despite the inability to govern within its own land. The international community has also continued to recognize "failed states" even during the period in which they are effectively failing. ${ }^{66}$

Finally, economic entities, such as the European Union, enjoy recognition of their sovereignty at the international level. Importantly, EU citizenship confers tangible, additional benefits to its citizens. ${ }^{67}$ Similarly, international law recognizes Taiwan's exercise of functional sovereignty on the international level, particularly in international economic affairs, though it is not recognized as a state. ${ }^{68}$

\footnotetext{
${ }^{59}$ Rayfuse, (W)hither Tuvalu?, supra note 58, at 10.

${ }^{60}$ See Sovereign Order of Malta, http://www.orderofmalta.org/?lang=en (last visited 16 June 2011) "The Sovereign Order of Malta is a sovereign subject of international law. The Order - which is based in Rome, in via Condotti - has its own Government, an independent magistracy, bilateral diplomatic relations with 104 countries and is granted the status of Permanent Observer in many international organisations, such as the United Nations". Ibid.

${ }^{61}$ See Acquaviva, supra note 43, at 353-357 (explaining that for a certain period after 1808, and then again between 1870 and 1929, the Pontiff had no jurisdiction over any territory at all before ruling Vatican City).

${ }^{62}$ See Holy See, US Department of State, http://www.state gov/r/pa/ei/bgn/3819.htm (last visited 16 June 2011).

${ }^{63}$ See Acquaviva, supra note 43, at 354-55.

${ }^{64}$ Rayfuse, (W)hither Tuvalu?, supra note 58. Indeed, Tibet's recent election of its newest Prime Minister provides an example of how the mechanics of exiled governance can operate. See Jim Yardley, Tibetan Exiles Elect Scholar as New Prime Minister, N.Y. Times, 27 April 2011. Admittedly, governments in exile have been contemplated as temporary and exceptional. McAdam, 'Disappearing States', supra note 38, at 112. I contemplate a deterritorialized state that exists in perpetuity subject to renewal by its diasporic citizens. See discussion infra Part IV.1. Further the circumstances of the endangered certainly justify exceptional responses. See discussion infra Part III.3.

${ }^{65}$ McAdam, 'Disappearing States', supra note 38, at 116.

${ }^{66}$ Ibid., at 111

${ }^{67}$ Rayfuse, (W)hither Tuvalu?, supra note 58, at 11.

${ }^{68}$ For a relevant and comprehensive discussion of Taiwan's international personality, see Acquaviva, supra note 43, at $369-75$
} 


\section{Diaspora, Cosmopolitanism, and the Shifting State}

Both cosmopolitan theory and the experience of the diaspora have served as a further counterweight to neat understandings of statehood, land, and citizenship. ${ }^{69}$ The Westphalian system fails to capture the experience of contemporary deterritorialized groups and individuals. The conventional conception of citizenship is one in which belonging to a nation-state affords an individual the ability to exercise civil, political, and social rights. According to Michelle McKinley, however, contemporary global movement forces a rethinking beyond the state, traditionally marked by borders. ${ }^{70}$ Indeed, the experience of members of diverse and multiple diasporas makes the cosmopolitan framework uniquely relevant for the twenty-first century experience of land and state for groups and individuals. Under this rubric, it becomes clear that deterritorialized statehood is not far-fetched; in fact there may already exist a rough blueprint for its theoretical and normative infrastructure in the diverse scholarship of cosmopolitan theory. ${ }^{71}$

\section{A. Diaspora and Cosmopolitanism}

Cosmopolitanism espouses the belief that all human beings, irrespective of state affiliation or political boundaries, belong to a single global community that should be acknowledged and cultivated. For the cosmopolitan, therefore, the notion that "blood and soil" must be inextricably intertwined is anathema. ${ }^{72}$ Further, this interlinkage is not only outmoded by failing to describe contemporary phenomena, it has very real consequences, particularly for climate migrants.

Refugees in particular "have always embodied the cosmopolitan ideal; their appeal to humanitarian principles resonates with broader calls for global citizenship". ${ }^{73}$ This is particularly true if applied to the unusual circumstances of the climate-displaced. This group, as we have seen, enjoys no special legal status to assist in their plight. It is a function of a dangerous adherence to the strictures of the nation-state paradigm. And, as McKinley recounts, critics argue that the nar-

\footnotetext{
${ }^{69}$ See generally Michelle A. McKinley, Conviviality, Cosmopolitan Citizenship, and Hospitality, 5 Unbound 55 (2009) (examining the relationship between refugeehood, statelessness, and cosmopolitan citizenship and using the prism of statelessness to explore the commonality between cosmopolitanism and nationalism with emphasis on deterritorialized modes of citizenship). McKinley argues that various non-Westphalian conceptions of the nation depart significantly from the territorially bounded framework of citizenship. Ibid., at 56 .

${ }^{70}$ Ibid., at 67. Indeed, McKinley's project vis-à-vis the cosmopolitan framework is to "advance transboundary solidarities that at the same time account for the compelling nature of locally produced and negotiated identities. All cosmopolitans have their personal histories that seem to justify their self-identified positions as global citizens". Ibid.

${ }^{71}$ Political institutions, moral norms or relationships, as well as shared markets or forms of cultural expression are among the diverse foci of cosmopolitan theory. See generally Cosmopolitanism, Stanford Encyclopedia of Philosophy, http://plato.stanford.edu/entries /cosmopolitanism/ (last visited 27 March 2011).

${ }^{72}$ McKinley, supra note 69, at 72. ("this invocation of blood and soil in tandem with citizenship demarcates the dividing line between nationalists (whether academic or popular) and cosmopolitans. Indeed, for the cosmopolitan, the combination of blood, soil, and citizenship seems to converge somewhere between the parochial and the eerily totalitarian".).

${ }^{73}$ Ibid., at 63 . Even though the appellation is unavailable to climate migrants for reasons discussed above, the similar experience of being displaced offers the same opportunity for reflecting on the contemporary relevance of the cosmopolitan framework.
} 
row focus on refugee status - consistent with the more narrow understanding of the state, rights, and affiliation-by organs like the UN Refugee Agency has detracted from its ability to advocate for people in "genuine conditions of distress" because they are not strictly political refugees. ${ }^{74}$ In fact, McKinley argues that cosmopolitan citizenship provides the normative foundation for an "alternative refugee regime" with an "expanded menu of rights", which the Westphalian model currently truncates. ${ }^{75}$ This expansion may well benefit the climate-displaced and provide viable responses to the legal knot that "environmental refugees", generally, introduce.

Even beyond the relief that cosmopolitan theory might provide for the protection of the climatedisplaced throughout the globe, cosmopolitanism provides a framework for the post-colonial, diasporic experience that already marks the identity of many today, including those from island nations. Post-colonial migration has produced a particular kind of citizenship. While citizenship is generally understood as territorially bound, post-colonial citizenships are deterritorialized and maintained through, among other things, travel, pilgrimage, labor migration, and "complex residential patterns that traverse boundaries". ${ }^{76}$ Further, territorial boundaries coupled with an effective national identity poorly reflect the contemporary experience in which global migration has produced "citizens" that exercise substantive citizenship in at least two states ${ }^{77}$-as well as citizens that enjoy long-distance bonds with nations from which they may have long emigrated.

Indeed, the post-colonial diaspora describes a present-tense experience of a deterritorialized nation, at least in part. As McKinley explains, the diaspora is another process of imaginary nation-building born of displacement, shares many characteristics of deterritorialized or longdistance nationalism, ${ }^{78}$ and is a "politically transformative space where legal boundaries matter less than transcendent solidarities". 79 The expatriate experience of Samoans and Tongans in Australia and New Zealand may well be instructive here. ${ }^{80}$

The critical lesson is that diasporic communities do not necessarily relinquish their substantive citizenship in their birth countries or other trans-boundary allegiances to people and culture. The case of diaspora is useful for conceiving of a viable nation-state that is both dispersed and deterritorialized. The analogy, admittedly, is not complete. For most members of the diaspora,

\footnotetext{
${ }^{74}$ Ibid., at 75 .

75 Ibid., at 76.

${ }^{76}$ Ibid., at 56. See also Francois Gemenne and Shawn Shen, Tuvalu and New Zealand: Case Study Report (2009) (describing the triple objective of Tuvalu's pursuit of migration opportunities in Australia, Fiji, and New Zealand; specifically, alleviating overpopulation in the capital, increasing remittances, and responding to fears of climate change).

${ }^{77}$ Ibid. Further, McKinley explains, the ethno-cultural nationalist similarly recognizes that people belong to other social groups beyond the state and often view membership in those groups as important. McKinley, supra note 69 , at 56 , at 72 .

78 Ibid., at 81 .

${ }^{79}$ Ibid., at 68.

${ }^{80}$ See generally Ilana Gershon, Viewing Diasporas from the Pacific: What Pacific Ethnographies Offer Pacific Diaspora Studies, 19 Contemp. Pac. 474 (2007); Helen Morton Lee, Tongans Overseas: Between Two Shores (2003); L.F. Va'a, Saili Matagi, Samoan Migrants in Australia (2001); Deborah C. Gough, Mobility, Tradition and Adaptation: Samoa's Competitive Advantage in the Global Marketplace, 4 Grad. J. Asia-Pac. Stud. 31 (2006).
} 
the existence of a tangible home remains, even if one never makes a visit home-and for some Pacific Islanders, land and territory does matter greatly, which I discuss in some detail below. ${ }^{81}$ However, for the purposes of the international law discourse, the trend of dispersed residence and transboundary loyalties has already disrupted the "neat correlation between citizenship and residence". ${ }^{82}$ To the extent that it ever was a firm condition, international law can abandon territory as a requirement of statehood and meaningful citizenship. ${ }^{83}$

\section{B.. Roots, Routes, and the Social Network}

The deterritorialized state must still pass muster for its prospective citizens; for while a virtual state bound by a social network may be clever and legally plausible, it must be satisfactory to its members. I suggest tangible benefits of maintaining a virtual state in the form of a Nation Ex-Situ in Part IV, keeping in mind the shared desire to retain sovereignty, culture, and local traditions. ${ }^{84}$ Here, I test the consistency and viability of this arrangement against the experiences to date of the citizens of endangered states.

The "roots and wings" 85 of the contemporary cosmopolitan is a particularly poignant metaphor for the Pacific Islander and provides support for the deterritorialized state. While the Pacific island region is notably heterogeneous, for the Pacific Islander, broadly speaking, land is vitally important, and for many cultures is inseparable from those who "belong" to it. The islanders' "roots" in the land is literal in meaning for some cultures in which the word for land describes both the soil and the placenta ${ }^{86}$ For the Marshallese, for example, the land possesses a "sacred or spiritual quality" and is the "very root of their worldly existence" ${ }^{87}$ Climate change will result in considerable spiritual and cultural loss, and any response to the loss of land and the concomitant rootedness and spirituality will do well to be mindful of that interrelationship.

Yet, there is a hybridity to the Pacific experience that is also relevant. Pacific island communities are marked by rootedness as well as migration. In his discussion of the meaning and importance of

\footnotetext{
${ }^{81}$ See discussion infra. McKinley also admits that it would be "irresponsible, if not cavalier, to proclaim effacement of borders. Borders do matter to those in situations of economic desperation and personal persecution". McKinley, supra note 69 , at 68 .

${ }^{82}$ Ibid., at 83.

${ }^{83}$ Before concerns of heading down a rabbit hole in which the state itself becomes meaningless arise, McKinley provides important analysis to allay those fears. Arguing that transmigrants "destabilize the cozy picture of the people-state-territory trilogy", McKinley follows with, "[b]ut only so much. Transnationalism still depends on an extended nationalist imaginative project, stopping short of civic cosmopolitanism. The Transmigrant engages in nationalism, albeit long distance nationalism". Ibid., at 81 .

${ }^{84}$ See Rayfuse, International Law, supra note 50, at 11 (describing the desires of Tuvalu and the Maldives to retain its sovereignty, culture, and traditions, including sovereignty over its maritime zones).

${ }^{85}$ McKinley, supra note 69, at 79 (citing Jeremy Waldron, What is Cosmopolitan? 8 J. Pol. Phil. 227, at 229-30 $(2000)$ ).

${ }^{86}$ See generally John Campbell, Climate-Induced Community Relocation in the Pacific: The Meaning and Importance of Land, in Climate Change and Displacement: Multidisciplinary Perspectives, supra note 36 [hereinafter Climate-Induced Community].

${ }^{87}$ Ibid., at 60.
} 
land in the Pacific, John Campbell cautions that it is important not to represent Pacific peoples and communities as being physically bonded by their location. ${ }^{88}$ In fact, in many Pacific communities "mobility and stability" coexist, and the "paradoxical notion of both roots and routes" is an important aspect of Pacific island lives. This hybridity exists, while people's sense of belonging and connection to place remains intact, even if they are at quite a distance from home. ${ }^{89}$

The Pacific region today is marked by migration, and Polynesia in particular has historically experienced significant movement. ${ }^{90}$ Residence in other Pacific Rim countries is already quite significant. ${ }^{91}$ Despite this distance from home, an extra-territorial sense of nationhood is maintained through remittances as well as family reunions. ${ }^{92}$ And it is this model of a vibrant social web across borders and regions that provides an example for the leadership of Kiribati as they contemplate a landless future. Indeed, "merits-based migration" to Australia and New Zealand is the long-term strategy of the government of Kiribati. ${ }^{93}$ This movement would replicate existing routes the people of Kiribati ("i-Kiribati") have traveled. Pockets of i-Kiribati communities will increase abroad, and could maintain traditions and culture and provide a smoother transition for newly arriving climate migrants. ${ }^{94}$

Of course, the actual loss of the land of origin is an unprecedented and potentially devastating exercise of migration and hybridity. ${ }^{95}$ To the extent that seas will continue to encroach due to climate change, the key question becomes what is the best way for the international community to facilitate the transition. A virtual nation-state, held together by a social network, may help ease the rootlessness that an uninhabitable territory will engender. ${ }^{96}$ This would not be an unreasonable

${ }^{88}$ Ibid., at 63.

${ }^{89}$ Ibid. Citing M. Jolly, Campbell explains, "But venturing on routes does not suggest the loss of roots, the perhaps less tangible, but nonetheless visceral, bonds that exist and connect people with their place. Many migrants, even long-term ones, still consider themselves to belong to their land, even if they are physically dislocated from it". Ibid.

${ }^{90}$ See generally Gershon, supra note 80; Jean Louis Rallu, Recent Trends in International Migration and Economic Development in the South Pacific, 11 Asia-Pac. Pop. J. 23 (1996). See also Gemenne and Shen, supra note 76 (stating that migration is a significant pattern of lifestyle, and even a social routine at times). Of migrants interviewed for research, many had migrated several times during their lifetimes, some up to eight times, which confirmed the unique and common 'migratory' nature of Tuvaluans. This, the authors contend, is common among Pacific islanders. Ibid., at 9,20 .

${ }^{91}$ Campbell, Climate-Induced Community, supra note 86, at 64.

92 Ibid., at 65.

${ }^{93}$ Jane McAdam, Swimming Against the Tide: Why a Climate Change Displacement Treaty is Not the Answer, 23 Int'l J. Refugee L. 2, at 20 (2011). This kind of migration would model current labor migration. I-Kiribati would undergo job training in sectors needing labor assistance in potential host-states.

${ }^{94}$ Ibid.

${ }^{95}$ See generally John Campbell, Climate Change and Population Displacement, at 2 (November 2009) (manuscript on file with author) [hereinafter Climate Change]. Campbell states that nearly all Pacific island communities that have a significant number of emigrants sustain a home population. "This notes of keeping the home fires burning is important in the context of communities that are very mobile... these roots enable many Pacific people to embark on journeys along routes. There is always somewhere to return to. But we have few examples, if any, of what happens when the roots no longer have land on which to become anchored". Ibid., at 5-6.

${ }^{96}$ See discussion infra. Further, Campbell suggests that climate change might not devastate some Pacific cultures. He explains, "Culture is ever-changing, and the fluidity of cultures and social structures in the Pacific(as elsewhere) 
departure from current international law. In fact, during previous times of resource scarcity, Pacific Islanders could move freely to other islands for relief; however, "the legal. . barriers to entry imposed by states today restrict freedom of movement". ${ }^{97}$ Because of these barriers, the movement that has helped these cultures adapt and thrive is foreclosed. Removing the legal impediments that limit free movement will avoid compounding the already difficult transition that the people of endangered states might have to make.

\section{Just and Appropriate Interpretation of International Law - and Extraordinary Circumstances-Favour the Deterritorialized State}

If the deterritorialized experience of other international governance entities or the diasporic modifications of the current Westphalian system are not themselves convincing, a reasonable extension of existing law applied to the extraordinary circumstances that climate change introduces might suffice. Quite simply, the presumption in international law of the continuity of an existing state ${ }^{98}$ is buttressed by arguments that would logically extend that presumption to the current endangered-states scenario. Similarly, appropriate interpretation of existing laws and the spirit in which they were drafted and ratified support expansive interpretation for the benefit of the peoples of endangered states. For example, if the objective of the UN Convention on the Law of the Sea is to create and maintain stability, certainty, and fairness in the governance of oceans, then a freezing of the baselines or the outer limits of maritime zones would be a consistent - and most just - means to preserve endangered states' rights to their marine resources. ${ }^{99}$ Similarly, the purpose of the Peace of Westphalia was ostensibly to provide security and stability, represented by borders and nation-states. That Westphalian system undergirds international organization today. Allowing the deterritorialized state-bound by culture and experience - to maintain a place in the international community would meet the objective purpose of the Westphalian system at a time when climate change poses an extraordinary threat to territorial integrity, as well as global peace and security.

Interpretation of international law without attention to context, object, and purpose, can stymie the potential for the law to reach the optimal — and perhaps most transformative - result. ${ }^{100}$ For endangered states, legal interpretation and analysis that does not have the principles of fairness and stability at root would be unduly cramped and dangerously unresponsive. Indeed, if the deterritorialized-state solution is not deemed viable or within the reasonable parameters of the current international law regime, then international law's relevance and legitimacy is

cannot be denied. It is possible after numerous generations that relocated people may find peace, no longer yearn for the land which was part of their ancestors, and build successful and prosperous lives in other environs. But, given the strength, tenacity and indivisibility of the person-community-land bond, relocation is bound to be disruptive for a considerable length of time over many generations".

${ }^{97}$ McAdam, 'Disappearing States', supra note 38, at 109.

98 Ibid., at 115-16.

${ }^{99}$ Rayfuse, International Law, supra note 50, at 6.

${ }^{100}$ See Aurelie Lopez, The Protection of Environmentally-Displaced Persons in International Law, 37 Envtl. L. 365, at 391 (2007) (quoting James C. Hathaway, The Rights of Refugees Under International Law 49 (2005)). 
questionable and could render current law a dangerous obstacle, thereby worsening the already dim climate forecast for endangered states. ${ }^{101}$

\section{The Nation Ex-Situ: Political Trusteeship And The Post-Climate State}

The Nation Ex-Situ would be a new entity in the international arena; yet, the framework for its execution is one of fair precedent. The political trusteeship system provides a helpful model for how to govern a nation without a habitable territory. The government of ex-situ nations would sit in a permanent location and manage the affairs of the state at a distance. Other scholars have introduced similar arrangements. In particular, Rosemary Rayfuse has suggested that an "authority" could continue to manage maritime zones to the benefit of the displaced population, through resource rents that could fund relocation and livelihood in the new host state. ${ }^{102}$ While the role of the government ex-situ would have a similar mandate, greater emphasis would be placed on preserving all elements of the nation-state that should endure extraterritorially-key among them are the persistence of culture, connection amongst its people, and the security and well-being of its citizens. The citizens of the ex-situ nation will almost certainly be scattered across the globe; and, the government of the Nation Ex-Situ can serve as a vital political and cultural nucleus.

In this section, I discuss the UN International Trusteeship System, on which I base this proposal. I then describe the mechanics of the Nation Ex-Situ. I conclude with a discussion of the benefits of this structure to the governments of the ex-situ nations, as well as their citizens.

\section{The Trusteeship Arrangement for Deterritorialized States}

Trusteeship arrangements have been a consistent feature of international law. Modeled on a common-law trust, political trustees administer the territories they hold in trust for the benefit of the inhabitants of that territory. ${ }^{103}$ The League of Nations, the United Nations, and other ad hoc international trusteeships have demonstrated the viability of these arrangements under international law. ${ }^{104}$ A critical difference in the contemporary application of the trusteeship system is that the purpose of the arrangement would be to maintain self-governance and self-determination, and elected citizens of the Nation Ex-Situ themselves would serve as trustees.

\footnotetext{
${ }^{101}$ One can understand these kinds of exacerbations as legal feedback mechanisms, or non-natural aggravations of climate change. Drawing on the positive and negative feedback loops climate scientists have postulated and observed, Professor David Caron provides a trenchant analysis of laws that are not themselves natural, but are human made elements of the existing legal order that, without amendment, "aggravate the suffering that will accompany climate change". Caron explains, "The greater the change, the greater the aggravation". David D. Caron, When Law Makes Climate Change Worse: Rethinking the Law of Baselines in Light of a Rising Sea Level, 17 Ecology L. Q. 621,623 (1990). There are myriad examples of these changes that are extant and uniquely relevant to climate change and the experience of the most vulnerable. I will elaborate on these in a forthcoming article, Climate Change and the Law: On Legal Feedback Mechanisms and Just Compensation.

102 Rayfuse, (W)hither Tuvalu?, supra note 58, at 11.

${ }^{103}$ Henry H. Perritt, Jr., Structures and Standards for Political Trusteeship, 8 UCLA J. Int'1 L. \& For. Aff. 385, at $389(2003)$.

104 Ibid., at 387-89.
} 
To ensure peace and security in transitions to self-government and self-determination, the United Nations established the international trusteeship system for certain designated trust territories. ${ }^{105}$ Because independence or self-governance was the purpose of each trust, the trustee was to develop the territory for self-government "while respecting the right of the peoples of the territory to permanent sovereignty over indigenous natural wealth and resources". ${ }^{106}$ Though the objects of focus in 1945 were quite specific, and territory was often central, the basic objectives of the trusteeship are applicable to the current climate scenario. Most relevant to the endangered states are the goals of furthering international peace and security, promoting the advancement of the peoples affected consistent with their freely expressed wishes, and ensuring the equal treatment in social, economic, and commercial matters for all Members of the United Nations. ${ }^{107}$

The UN Trusteeship System expressly excluded the territories that had become Members of the United Nations. This exclusion was consistent with the principle of sovereign equality, which the UN Trusteeship System was to respect. ${ }^{108}$ In the current climate change context, however, the introduction of a new kind of trusteeship system for current member states is not only appropriate, it is also necessary to recognize the sovereign equality of the endangered state. In other words, for these states to persist as international personalities, they must contemplate a revised trust arrangement. The UN Trusteeship System serves as a precedent to demonstrate the viability of this kind of removed governance and provides a structure that the international community can most easily replicate given earlier experience. A few departures from the original UN Trusteeship System will produce a more appropriate structure for endangered states.

The key departure will be the extent to which the United Nations, particularly the Security Council or the General Assembly, direct the terms and functioning of the trusteeship arrangement and the subsequent Nation Ex-Situ. ${ }^{109}$ Under the traditional arrangement, another state, a group of states, or the United Nations itself, holds the territory under supervision in trust. ${ }^{110}$ Here, the UN's absence in the internal structuring of the arrangement would be essential. To respect the continued sovereign equality of the endangered state, the United Nations and member states would act only to support the transition to, and establishment of, ex-situ nationhood. At the same time, if it is anchored in a UN structure, the establishment of the ex-situ nation can benefit from having the international community play a significant supportive role in administering and financing the ministerial affairs of the deterritorialized state. In practice, the United Nations might establish an office with the express purpose of facilitating the transition and long-range governance of endangered states, all of which are marked by their limited resources. A secretariat

105 The UN Trusteeship System focused primarily on post-colonial transitions. See ibid., at 396. The endangered states scenario is quite different in provocation, but could benefit from the structure and lessons learned from the UN system.

106 Ibid.

${ }^{107}$ UN Charter, Ch. XII, art. 76.

${ }^{108}$ UN Charter, Ch. XII, art. 78.

109 This kind of oversight was an element of the UN Trusteeship System. See, e.g., UN Charter Ch. XIII, arts. 86-7. For a specific recommendation on exact legal mechanism for the creation of these authorities, see discussion infra page 22.

${ }^{110}$ Perritt, supra note 103 , at 390 . 
would serve as the locus of the UN administrative support and might also serve as a hub for all Nations Ex-Situ to work collaboratively and synergistically for the benefit of current and future generations. ${ }^{111}$

With these modifications, the structure of the historical trusteeship system remains instructive here. In the case of endangered states, appointed members of these states supported by the UN would serve as the political trustee. The trustee would first serve as an interim body that governs alongside the existing in-situ government of the endangered state, to facilitate an orderly transition for the peoples and governance mechanisms of that state. ${ }^{112}$ Drawing on relevant international interventions, ${ }^{13}$ the United Nations could help establish, and other states recognize, the Interim Mission of a given endangered state. For example, the Interim Mission for the Republic of the Marshall Islands Ex-Situ would serve as the authority to administer all provisions related to the transition of the endangered state from its current status to a purely deterritorialized entity. ${ }^{114}$ The decisions that the interim body would make might include: (i) determining appropriate modifications to the current in-situ political and economic institutions; (ii) enactment of legislation for continued citizenship as well as distribution of monies from resource rents, adaptation funding, or compensation from other international entities, ${ }^{115}$ among other things; (iii) resolution of property disputes and appropriate regimes for compensation; and, (iv) a mechanism for determining what is in the best interest of the diaspora and representing the people in international affairs accordingly. ${ }^{116}$ The most significant element of this would be to exercise diplomatic protection of the diaspora as its members reside in other sovereign host states. ${ }^{17}$ This would fall under the general ability to enter into negotiation and arrangements with other states and inter-governmental organizations as a sovereign entity.

\footnotetext{
111 The Trusteeship System contemplated "ambiguous" beneficiaries, including future generations. Ibid., at 390. What this meant in practice is that the beneficiary in Kosovo could be a state that subsequently came into existence, such as an independent Kosovo. The obvious corollary here would be the beneficiaries, or future citizens, of the $e x$-situ nation.

112 This kind of intermediate body has precedent. See ibid., at 389. Perritt describes intermediate sovereignty and phased recognition as a kind of "soft trusteeship" and provides historical example of its application. Ibid.

113 See generally ibid. Here the most relevant corollary is the UN Interim Mission in Kosovo (UNMIK) that served as trustee, holding legal title over the res - that is, the property comprising Kosovo. For the UNMIK, the equitable title vested in the people of the trust territory as beneficiaries. Ibid., at 390. Perritt identifies this as the best example of a contemporary political trusteeship. Ibid., at 402. Perritt identifies four additional international interventions after the formal termination of the UN Trusteeship System that, he argues, exhibit the continued viability of the political trusteeship concept. Ibid., at 398.

114 See further discussion infra. Of course, the existing leadership of an endangered state may opt to serve as the interim authority.

115 See generally Maxine Burkett, Climate Reparations, 10 Melbourne J. Int'l L. 509 (2009). The Norwegian Refugee Council similarly contemplates compensation for property and land lost, as well as assistance in resettling and re-establishing livelihoods and residence elsewhere of those affected. Kolmannskog, supra note 7, at 12.

116 See Perritt, supra note 103, at 421. Rayfuse envisions an "authority" that would continue to represent the state at the international level as well as the rights and interests of its citizens vis-à-vis their new host state or states. Rayfuse, (W)hither Tuvalu?, supra note 58, at 11. These rights could include the right of dislocated citizens to maintain their original personal, property, cultural, linguistic and nationality rights for themselves and descendants, while simultaneously being granted full citizenship rights in the new 'host' state or states. Ibid.

${ }^{117}$ See McAdam, 'Disappearing States', supra note 38, at 117.
} 
Once the moment of complete territorial dislocation occurs for the relevant population, the interim body would combine with the dislocated governing body to form a single locus of power. ${ }^{18}$ This would be the new central government of the Nation Ex-Situ. While this new body would be distinct in name, the manner in which it operates-namely for the benefit of its people, even if outside of a territory and entirely diasporic-will be almost identical to that of the interim body. In this sense, the new ex-situ government would be an element of the overall trusteeship model, in that the Nation Ex-Situ will serve the function of coordinating all social, economic, and commercial matters related to its former territory for the benefit of its dispersed citizens.

The endangered states electing to participate, and their citizens, will determine the specific terms of the trusteeship through iterative processes of evaluation and amendment. ${ }^{119}$ The Trusteeship Agreement would detail how the endangered state will be governed from transition and throughout the period of uninhabitability. The latter period could in theory exist indefinitely. It is important to note, however, that a key element of the Agreement is that though this ex-situ nationhood would be designed to exist in perpetuity, it would be subject to a decision by members of the disembodied state to dissolve at any time. ${ }^{120}$ Thus, the trusteeship would establish an administering authority for the interim, as well as a permanent ex-situ entity that would be responsive to the necessarily evolving needs of its diaspora. ${ }^{121}$ Again, the United Nations would serve a supporting administrative role for as long as the Interim Mission and the Nation Ex-Situ choose to exist.

Of course, the legitimacy of the Nation Ex-Situ would be subject to the acquiescence of the international community, including the presumably multiple host states to which islanders will

\footnotetext{
${ }^{118}$ It is possible that certain nations will be in a liminal space for quite some time. There may not a be a distinct moment of clear deterritorialization. In fact, the current uncertainty of climate forecasts could not necessarily rule out the possibility that a nation would be substantially compromised by rising sea levels, yet able to host a population of citizens, even if quite small, for generations. The question then becomes, how do you administer an interim mission for, say, fifty years? Is this even desirable? In response, I would suggest that each state and its citizens will have the latitude to make the decision for themselves whether to dissolve or exist in parallel through the instruments available to them in the Interim Mission. I thank Robert Perkinson for raising this important logistical challenge.

119 This and similar recommendations below draw from the Trusteeship System detailed in the UN Charter. This particular recommendation mirrors Article 79 of the UN Charter. See also Perritt, supra note 103, at 432. Perritt explains that the political trusteeship must accurately ascertain the will of the local population and whether they want to form their own state. If the population desires to form a separate state, the trusteeship must then determine whether statehood is feasible and if so, prepare the population and territory for legitimate statehood under international law. Ibid.

${ }^{120}$ Like other nations, the Nation Ex-Situ should not have a prescribed expiration date at its inception. This is critical to my proposal. The Nation Ex-Situ should be functionally indistinct from its territorialized state counterparts in that a decision to dissolve is integral to the exercise of its sovereignty. Therefore, the state and its nationals are the only ones that can legitimately make this decision. Importantly, Rayfuse imagines something quite different. Indeed, she argues that it is useful to view the trustee-type arrangement as transitional lasting one generation or one human lifetime. Rayfuse, (W)hither Tuvalu?, supra note 58, at 13. In this thirty to one hundred year period it is likely that much else in the international legal regime will have to be reconsidered and reconfigured, she maintains. Ibid. While I agree with her assessment regarding the inevitable and significant changes to the law that will necessarily emerge over the next few decades, I argue that guarantees of sovereignty and self-determination require that $e x$-situ nationhood remain constant.

${ }^{121}$ See, e.g., UN Charter, ch. XII, art. 81.
} 
migrate. In his discussion of the structures and standards of political trusteeship, Henry Perritt explains that international legitimacy is necessary "so that a critical mass of the international community will recognize and protect the trustee and its successors. Without international legitimacy, the trustee will likely lack necessary resources, and may face state-sponsored resistance". ${ }^{122}$ The unique reasons for deterritorialized statehood and methods by which the Nation Ex-Situ status would emerge favour international acceptance. Further, the character and functional purpose of the Nation Ex-Situ buttress the legitimacy of this new kind of statehood. In addition to delivering a tangible benefit and services to its citizens, the ex-situ nation will help maintain the personal and group pride, ideology, and traditional custom of the territorialized entity it succeeds. ${ }^{123}$ Ultimately, however, the extent to which the international community believes that this new status is consistent with international law will likely be determinative. The presumption in favour of the continued existence of the state and prevention of statelessness for individuals supports acceptance. Further, scholars maintain that state practice suggests that the international community might well recognize on-going statehood "even when facts no longer seem to support the state's existence". ${ }^{124}$ Nation ex-situ status would be a definitive response to the dilemma facing an endangered state, which also ensures self-determination, governmental effectiveness, economic stability, and the protection of rights. ${ }^{125}$

In light of this need for recognized international legitimacy and the value of this new status, it will be important for the international community to institutionalize international acceptance through an instrument - such as a UN resolution or treaty - that unambiguously vests sovereignty in the Nation Ex-Situ. ${ }^{126}$

\section{The Legitimate Post-Climate State and Citizenship for the Post-Climate Diaspora}

The Nation Ex-Situ would be a creature of the new political and legal environment that climate change may force. If properly planned and supported, there could be clear benefits for the new state and, in particular, its citizens. In addition to the maintained and effective participation of endangered states in the international community, the Nation Ex-Situ can guard against the slow failure of a state that is overcome by increasing outward migration. The loss

122 Perritt, supra note 103 , at 424. Similarly, internal legitimacy is necessary "so that the population will not, to borrow Gandhi's term, 'withdraw its support' from the government". Ibid. Perritt identifies factors to determine internal legitimacy, including charismatic leadership, group pride, and the end to national stage conflict. Ibid., at 442.

123 See Perritt supra note 103, at 425 (identifying modern criteria for both international and internal legitimacy).

${ }^{124}$ McAdam, 'Disappearing States', supra note 38, at 117.

125 See Perritt supra note 103, at 428, 430 (identifying factors that increase international legitimacy).

126 See e.g., ibid., at 420 . The international community can do this categorically. In other words, the "community of states. . can lay down rules in treaties or in customary international law that automatically confer statehood when certain requirements are met" for endangered states. See ibid. A Chapter VII UN Security Council Resolution, binding on all UN member states is also plausible. UN Charter, Ch. VII: Action With Respect To Threats To The Peace, Breaches Of The Peace, And Acts Of Aggression. The reluctance of the Security Council to take up climate change as a threat to peace and security, a request made by vulnerable island nation-states, does not suggest near-term involvement in this issue, however. 
of human capital that accompanies large and sustained emigration can render a state unable to provide basic social services and engage in productive activities. ${ }^{127}$ Indeed, this was the concern of Ambassador Jumeau, discussed above. Similarly, Walter Kalin, the Representative of the UN Secretary-General on the Human Rights of Internally Displaced Persons, has stated: "People from islands and territories will start to migrate, legally or with an irregular situation, and overall the society will slowly disintegrate. For a certain time there will be a government, but it will be a fiction. It will be a slow process of whole nations dying in the social sense in addition to the geographical sense". ${ }^{128}$ As climate change compromises the vital coastal resources of a state, coupled with the negative effect of outward migration, ${ }^{129}$ state failure is a very real possibility. Large-scale resettlement that occurs prematurely can also weaken a country's claims to compensation for the socio-economic impacts that climate change introduces. $^{130}$

An interim body and clear deterritorialized successor entity can ensure a robust nation-state while facilitating the necessary resettlement of its people. During the process of resettlement, the interim body would oversee its efficacy and ensure that human rights are respected and that vulnerability is not increased because of the move. Once resettled, the diaspora would maintain citizenship to a state that has the well-being of its dispersed nationals as a singular concern.

As a practical matter, the designation of nationality allows the Nation Ex-Situ to exercise jurisdiction over its citizens. ${ }^{131}$ Absent that recognized affiliation, other states could seek to exercise jurisdiction over a stateless individual. In the case of the climate migrants from endangered states, they would enjoy citizenship in their host state as well as their Nation Ex-Situ. ${ }^{132}$ The benefit of this kind of dual citizenship mirrors the general advantage of membership-that is, states in theory protect their citizens from molestation. ${ }^{133}$ Here, by recognizing host-state citizenship, the climate migrant will enjoy some semblance of equal membership in their new host state of

${ }^{127}$ See UN Secretary-General, Climate change and its possible security implications, at 17, UN Doc. A/64/350 (11 September 2009).

${ }^{128}$ Morris, supra note 25.

${ }^{129}$ McAdam makes a similar suggestion, positing: "Paradoxically, planned and staggered migration over time - the solution favoured by Pacific islanders if in situ adaptation to climate change is not possible - may ultimately start to erode longer-term claims to continued sovereignty and statehood, since the state's 'disappearance' may begin once the bulk of the permanent population has moved abroad and obtained a legal status in a new country (either through naturalization or by being born a citizen there)". McAdam, 'Disappearing States', supra note 38, at 129.

${ }^{130}$ See Gemenne and Shen, supra note 76. See also Kolmannskog, supra note 7, at 12.

${ }^{131}$ See Jeffrey L. Blackman, State Successions and Statelessness: The Emerging Right to An Effective Nationality Under International Law, 19 Mich. J. Int'l L. 1141, 1149 (1998).

132 This claim to nationality in the host state would be a reasonable right that would accompany resettlement. The full details of this arrangement, and other resettlement rights, are beyond the scope of this paper. This granting of nationality would be consistent, however, with the individual right to a nationality set out in Article 15 of the Universal Declaration of Human Rights. See generally ibid., at 1172, 1175 (discussing the right to nationality and dual citizenship). Further, to prevent temporary statelessness, dual nationality may need to be permitted at least for a transitional period. See UNHCR, Climate Change, supra note 30, at 3.

${ }^{133}$ See Blackman, supra note 131, at 1150. 
residence. At the same time, the ex-situ nation will advocate on behalf of its citizens, particularly in circumstances in which they are less well off due to resettlement. ${ }^{134}$

The benefits of citizenship are coupled with the psychosocial benefit of the perpetuation of the culture and traditional lifeways indigenous to the endangered state. There is also hope for continued community. This can occur in at least three ways. First, an identity based on formal membership can be passed down through generations. Even without a physical location, the sense of bonded community will continue to have multigenerational relevance and strength. Second, the nationals of the ex-situ nation can continue to enjoy a shared purpose. Indeed, this appears to be the most powerful binding force for the Sovereign Order of Malta, whose members remain bonded by history, spirituality, and service. ${ }^{135}$ The possibility of reunion in other locations is a third method for continued cultural identity. Of course, the means by which the diaspora maintains its lifeways through ex-situ nationhood would be decided by its members. In the ways described, however, community can persist. Though tenuously, cultural identity will survive territory even at a significant distance. Indeed, to underestimate the benefit of some form of cultural survival could further injure the people of these endangered states. While political identity is second to "home", deterritorialized statehood may well ensure some semblance of community and culture that is itself integral. ${ }^{136}$

\section{The Republic of the Marshall Islands Ex-Situ (RMIes)}

There is some indication that retention of state identity for control over resources and other assets is welcome from the perspective of the endangered state. The President of Kiribati has proposed the establishment of a small government outpost on the state's only high ground for this exact purpose. The particular history of an endangered state, along with its climate forecast, may reveal differing advantages and disadvantages of this arrangement. Here, I look at the prospects of a Republic of Marshall Islands Ex-Situ (hereinafter RMIes) and identify issues to consider.

The Republic of the Marshall Islands (hereinafter RMI) is one of four atoll-only nation-states in the Pacific. It is, as a result, particularly vulnerable to climate-related loss of territory. ${ }^{137}$ That prognosis alone makes the proposed ex-situ status particularly relevant, and the emergence of RMIes a distinct possibility. The palatability of that potential future should be judged against the RMI's historical experience with trusteeship systems. Indeed, the RMI, along with a handful

\footnotetext{
134 This scenario is not farfetched. See Kolmannskog, supra note 7, at 12 (explaining that involuntary relocation and resettlement rarely leads to improvements in quality of life of those moved; therefore, moving communities in anticipation of climate change may precipitate vulnerability more than it avoids it). This decline in livelihood due to climate-related relocation and resettlement may have precedent. See Tangata Vainerere, Climate Change Refugees Return to Bougainville Atolls, PACNEWS, 22 July $2009,<$ http://www.pina.com.fj>.

${ }^{135}$ See Sovereign Order of Malta, supra note 60.

${ }^{136}$ Indeed, the Jewish diaspora may well be the most poignant example of enduring community and cultural bonds, despite a long history with deterritorialized existence.

${ }^{137}$ Zetter, supra note 15 , at 396 . Four completely atoll nations in the Pacific are particularly vulnerable. They are Kiribati, Tokelau, Tuvalu, and the Republic of the Marshall Islands.
} 
of other Pacific island states, operated under the trusteeship agreement designating the Trust Territory of the Pacific Islands (TTPI). ${ }^{138}$ The TTPI was a strategic trust, under which the United States was responsible only to the Security Council for its administration, and was given preferential treatment in economic matters, among other things. ${ }^{139}$ This trust relationship with the United States succeeded both German colonization and Japanese administration of the islands, and preceded the Compact of Free Association with the United States that established Marshallese independence in 1986. ${ }^{140}$ The Compact provided, among other things, sustained economic support by the United States, and gave full authority to the United States for the security and defense of the RMI. Indeed, the RMI is quite dependent on the United States, despite its sovereign status. ${ }^{141}$ In essence, the RMI has had extensive experience with external administration, and a very short history of independent statehood, ${ }^{142}$ which itself has been colored by the unique nature of the Compact of Free Association. ${ }^{143}$

Others may argue that the complex history that the RMI has had with its own sovereignty may support a simple return to familiar trusteeship arrangements with-most likely-the United States. Alternatively, a further amendment of the Compact that contemplates self-governance in free association with the United States, with specific negotiation around the eventual loss of territory and resettlement needs, may seem appropriate. ${ }^{144}$ However, even if the United States were to absorb the population of the RMI, and the United States further chose to represent vigorously the interests of the Marshallese, it seems that the existence of the RMIes would remain necessary as a practical matter. First, the United States would need to maintain a relationship with some specific entity for the compact or trust arrangement to have any meaning. In this case, that would most sensibly be the RMles. Further, the RMIes may ease the devastation that will almost certainly accompany the inevitable rupture of the characteristic land-person-community bond in the Pacific discussed above.

Consideration of the non-institutional relationship the Marshallese have with their current territory may indeed be the strongest argument for establishing the RMIes. As discussed in Part III, the land is imbued with significant spiritual meaning for the Marshallese. For any community or culture, even those of the diaspora, the existence of the home country is pivotal to identity. Yet, while the devastation that will come with the loss of these lands seems an unavoidable consequence, the experience of relocation and resettlement might be eased by a concerted

\footnotetext{
${ }^{138}$ See generally Peter D. Trooboff, Foreign State-Republic of The Marshall Islands-TreatiesSovereignty-Trust Territory Of The Pacific Islands, 83 Am. J. Int'1 L. 583 (July 1989).

${ }^{139}$ Ibid., at 584. See also Larry Wentworth, The International Status and Personality of Micronesian Political Entities, 16 ILSA J. Int'1 L. 1 (Spring 1993).

${ }^{140}$ The Amended Compact of Free Association came into force in 2004.

${ }^{141}$ See CIA, The World Factbook, Australia-Oceania: Marshall Islands, available at <https://www.cia.gov/library/ publications/the-world-factbook/geos/rm.html> (providing statistics that demonstrate the importance of USgovernment assistance).

142 The RMI only joined the United Nations in September of 1991.

143 See Wentworth, supra note 139 (describing the basic principles of the Compact).

${ }^{144}$ See, e.g., McAdam, 'Disappearing States', supra note 38, at 126.
} 
effort to maintain "community lore and law" 145 — which continued sovereignty under RMIes can guarantee. ${ }^{146}$ The RMIes would quite literally be the tie that binds.

While recognizing that this arrangement is wholly suboptimal to remaining at home without devastating climate change, I suggest that ex-situ nationhood is the most appropriate response in the Pacific. In fact, many Pacific island communities are marked by their history of remarkable migration and relocation over great distances. This would clearly be the next and most challenging frontier. ${ }^{147}$

\section{Legal Evolution in the Post-Climate Era}

\section{The Post-Climate Era}

Climate change has introduced the potential for a seismic shift in the way we have organized human systems on the planet. Our thorough reworking of our environment will necessarily impact the legal, political, and economic systems in which they were conceived, developed, and globalized. At this moment in geological history, when the impacts of climate change are increasingly palpable and understood, I suggest that we are embarking on a post-climate era in law and human society.

In this period, the human systems that developed under the relatively stable climate will confront challenges to their baseline assumptions and rules of participation. I suggest that an appropriately unified and thorough post-climate theory will emerge. The details of that theory are beyond the scope of this article; however, the instigating environment for this inquiry becomes clear in this explication of ex-situ nationhood. As I discuss below, in the post-climate era, our legal systems will not be immune to dramatic change. Indeed, those early signs of disparate critique are emerging first-perhaps unsurprisingly_in the environmental and international law arenas.

\section{Climate Change is as Much a Problem of Pollution as Legal Evolution ${ }^{148}$}

The complexity, reach, and enormity of climate change may continue to confound conventional understandings of our legal and political systems. Though perhaps the most perplexing, climate-

145 Campbell, Climate Change, supra note 95, at 25.

${ }^{146}$ Or at least some semblance of community lore and law. In his discussion of climate change and the importance of land in the Pacific, Campbell contemplates a more favourable transition similar to what I describe here. See ibid.

${ }^{147}$ See Maxine Burkett, In Search of Refuge: Pacific Islands, Climate-Induced Refuge, and the New Legal Frontier, 98 AsiaPacific Issues 1 (2011).

${ }^{148}$ Robin Kundis Craig, "Stationarity is Dead"-Long Live Transformation: Five Principles for Climate Change Adaptation Law, 34 Harv. Envtl. L. Rev. 9, at 27 (2010) (citing Ted Nordhaus and Michael Shellenberger, Breakthrough: From the Death of Environmentalism to the Politics of Possibility 8 (2007): "To describe these challenges as problems of pollution is to stretch the meaning of the word beyond recognition. Global warming is as different from smog in Los Angeles as nuclear war is from gang violence. The ecological crises we face are more global, complex, and tied to the basic functioning of the economy than were the problems environmentalism was created to address forty years ago. Global warming threatens human civilization so fundamentally that it cannot be understood as a straightforward pollution problem but instead as an existential one. Its impacts will be so enormous that it is better understood as a problem of evolution, not pollution".). 
induced migration and endangered statehood are just one subset of the many unique and unprecedented phenomena that the law will have to govern. As currently organized, the law is ill-equipped to deal with an inherently cross-cutting event like climate change. As Jane McAdam convincingly states, "The traditional ways in which law and policy have been divided into 'fields' of inquiry and operation, such as 'human rights', 'trade', 'development' and so on, do not reflect the messy, complex interconnectedness of the issue". ${ }^{149}$ Though here she speaks specifically of environmental migration governance, this assessment is true of many climate issues with which decision-makers currently grapple — or which they ignore. ${ }^{150}$ On the one hand, the residence of climate migrants in a legal no-man's land is a function of this messy, complex interconnectedness. Further, climateinduced migration raises difficult policy issues related to immigration, development, and the environment, among others. As such, no one legal and policy community can claim exclusive ownership of the issue and move it along the policy agenda. ${ }^{151}$ On the other hand, that complexity also serves as a facile excuse not to address these confounding legal by-products of a changing climate, making the potentially most dire and tragic consequences the easiest to sidestep.

Coherency and consistency are oft-cited reasons for classifying law into fields and finding and creating patterns within those fields. ${ }^{152}$ As one legal scholar emphatically stated, "Justice requires consistency". ${ }^{153}$ Climate change, itself defined by inconsistency, demands a rethinking of deeply held legal precepts. This is, in essence, what it means to adapt. In the case of endangered states, ex-situ nationhood is a clear adaptation-and, those nations and the international community would need to evaluate its efficacy periodically. Yet the notion that an appropriate response is an ongoing and iterative experiment challenges the law's claim to finality, a core principle of procedural and substantive fairness in the law. ${ }^{154}$ Until the post-climate era, one could seek legal solace in the insistence on classification, consistency, and settled expectations.

The need to incorporate adaptation to climate change into environmental management, for example, has inspired a great degree of soul-searching among many environmental law scholars. These scholars express an existential angst as climate change forces their "field of law" not only to accommodate adaptive management, but also to reorient itself to effectively execute such management over an indeterminate time scale. As J. B. Ruhl explains, "Environmental law... will undergo its own structural transformation regardless of the normative adaptation goals we set for it, which in turn will limit the normative goals we can hope to achieve with it" ${ }^{155}$ This transformation is not exclusive to environmental law.

\footnotetext{
${ }^{149}$ McAdam, Environmental Migration, supra note 14, at 6.

150 These include the global security issues that accompany increased resource scarcity down to the appropriate local land use policies that are consistent with sound adaptation to climate change.

${ }^{151}$ Boncour and Burson, supra note 17 , at 6 .

152 Todd S. Aagaard, Environmental Law as a Legal Field: An Inquiry in Legal Taxonomy, 95 Cornell L. Rev. 221, at $221(2010)$.

153 Ibid., at 224.

154 A. Dan Tarlock, The Nonequilibrium Paradigm in Ecology and the Partial Unraveling of Environmental Law, 27 Loy. L. A. L. Rev. 1121, at 1140 (1994).

155 J. B. Ruhl, Climate Change Adaptation and the Structural Transformation of Environmental Law, 40 Envtl. L. 363 , at $377(2010)$.
} 
International law has been similarly cabined, with "insufficient attention paid to the duty to read text in line with the context, object and purpose". ${ }^{156}$ In the context of climate-induced migration, the failure of treaty law to play a genuinely transformative role in the international system of law and governance is already evident. ${ }^{157}$ Ruhl correctly states that "climate change ... will also exert tremendous structural pressures on the very design and implementation of law itself". ${ }^{158}$ International and environmental law - as well as the laws of national security, immigration, public health, housing and human rights, among many others-must cooperate and simultaneously embrace transformation.

Climate change takes us to a legal frontier. In other words, novel scenarios push current legal fields to their extensive margins, and force consideration beyond their existing boundaries. Further, notions of consistency and finality, like the state-territory link, are increasingly moribund. ${ }^{159}$ For example, a single integrated legal instrument would be the most coherent and structurally appealing approach to climate change governance, generally, and migration and endangered statehood, specifically. Yet, it is probable that the emerging legal architecture for climate change will contain overlapping instruments, specific to the circumstances of disparate peoples and environments. Such a complex, layered, and inter-linked regime is currently disfavoured among legal scholars, as it might pose considerable legal and governance challenges. Yet, if the law is left in its current state, the challenges to law and governance are as great under any climate scenario. This is evident in the lack of a legally cognizable definition for migrants, much less a well-formulated legal and policy framework to govern their migration after twenty years of global awareness of the dilemma. The law would do well to embrace layers and inter-linkages-that is the essence of its successful transformation. Indeed, chasing coherence discourages experimentation in lawmaking, ${ }^{160}$ exactly what may be needed in the endangered-states context-and what will be a core element of post-climate governance.

The plight of endangered states and their citizens serves as an opportunity to explore the full possibilities of the legal frontier and learn key lessons for future application along the way.

\section{CONCLUSION}

The evidence increasingly suggests that effective management of climate-induced migration and disappearing states will benefit both regional stability, through the minimization of humanitarian crises and avoided conflicts, and preserved socioeconomic development. ${ }^{161}$ Avoiding the poverty and suffering that might arise from continued inaction compels immediate implementation of

\footnotetext{
${ }^{156}$ James Hathaway, The Rights of Refugees Under International Law 49 (2005) (quoted in Aurelie Lopez, The Protection of Environmentally-Displaced Persons in International Law, 37 Envtl. L. 365, at 391 (2007)).

${ }^{157}$ Ibid.

158 Ruhl, supra note 155 .

${ }^{159}$ Of course, there is considerable question as to whether or not this is a real versus strongly perceived characteristic of the law. See e.g., Aviam Soifer, Reviewing Legal Fictions, 20 Ga. L. Rev. 871 (1986).

${ }^{160}$ Aagaard, supra note 144, at 235.

${ }^{161}$ Asian Development Bank, supra note 13.
} 
multi-level policy interventions and concordant governance systems. Challenges to statehood and the need for substantial, if not total, relocation over a relatively short time-scale make smallisland states distinct enough to warrant a swiftly executed initiative tailored to their plight. This will not provide the kind of certainty required of the law. ${ }^{162}$ It will, however, set the framework for sequenced and measured responses appropriate for particular scenarios and geographical regions.

Exhaustive elaboration on the theory and implications of a new governance model in an era of climate change is beyond the scope of this article. ${ }^{163}$ It appears, however, that we may be embarking on a new legal and political epoch, in which uncertainty, inconsistency, and phenomena without precedent may indeed become the norm. It is not clear what exact changes it will yield, but it will be key to identify the principles we use to engage them.

${ }^{162}$ McAdam, Environmental Migration, supra note 14, at 8.

${ }^{163}$ I will elaborate on this in my next piece, Post-Colonial, Post-Modern, Post-Climate: Lessons for Understanding Power and Re-Building in an Era of Change. 